\title{
Do Hematological Parameters Have a Significant Role in Predicting the Results of Prostate Biopsies?
}

\author{
Hematolojik Parametrelerin Prostat Biyopsisi Sonuçlarını \\ Öngörmede Önemli Bir Rolü Var mı?
}

\section{Özgün Araştrrma}

Research Article

\author{
Ali Borekoglu $\odot$, Deniz Abat $\oplus^{\oplus}$, Huseyin Eren ${ }^{\oplus}$, Adem Altunkol ${ }^{\oplus}$, Onur Karslı ${ }^{\oplus}$, \\ Selçuk Yaylacı ${ }^{\circledR}$
}

\begin{abstract}
Objective: To assess the predictive role of hematological parameters on the results of prostate biopsies.

Method: We evaluated patients who underwent ultrasound-guided prostate biopsies between January 2014 and April 2016. The patients were divided into two groups according to their histopathological results: as patients with and without established diagnosis of prostate cancer. White blood cell, neutrophil, lymphocyte, platelet counts, hemoglobin level, hematocrit, red cell distribution width, mean platelet volume, platelet distribution width and plateletcrit were analyzed before biopsy. Additionally, neutrophil-to-lymphocyte and platelet-to-lymphocyte ratios were calculated. These parameters were compared between the two groups and statistically analyzed.

Results: Prostate cancer was detected in 38 (30.25\%) patients, and benign conditions (prostatic hyperplasia or chronic prostatitis) were detected in 88 (69.85\%) patients. There was no statistically significant difference between the patients with prostate cancer and patients with benign conditions according to the white blood cell, neutrophil, lymphocyte, platelet counts, hemoglobin level, hematocrit, red cell distribution width, mean platelet volume and platelet distribution width and plateletcrit. Additionally, there were no statistically significant differences between the groups regarding the neutrophil-to-lymphocyte and platelet-to-lymphocyte ratios.

Conclusion: Hematological parameters do not play a significant role in predicting prostate biopsy results. More sophisticated studies are needed to further evaluate this issue.
\end{abstract}

Keywords: Biopsy, neutrophil-to-lymphocyte ratio, platelet-to-lymphocyte ratio, prostate

öz

Amaç: Hematolojik parametrelerin prostat biyopsisi sonuçları üzerindeki öngörücü rolünü değerlendirmek Yöntem: Ocak 2014-Nisan 2016 tarihleri arasında ultrason eşliğinde prostat biyopsisi yapılan hastaları değerlendirdik. Hastalar histopatolojik sonuçlarına göre iki gruba ayrıldı: prostat kanseri saptanan ve saptanmamış hastalar. Biyopsi öncesi eritrosit sayısı, nötrofil sayısı, lenfosit sayısı, trombosit sayısı, hemoglobin düzeyi, hematokrit, kırmızı hücre dağılım genişliği, ortalama trombosit hacmi, trombosit dağılım genişliği ve trombosit incelemesi yapıldı. Ek olarak, nötrofil lenfosit oranları ve trombosit lenfosit oranları hesaplandı. Bu parametreler iki grup arasında karşılaștırıldı ve istatistiksel olarak analiz edildi.

Bulgular: Prostat kanseri 38 hastada $(\% 30,25)$ ve benign prostat hastalıkları (prostat hiperplazisi veya kronik prostatit) 88 hastada $(\% 69,85)$ tespit edildi. Prostat kanserli hastalar ile eritrosit sayısı, nötrofil sayısı, lenfosit sayısı, trombosit sayısı, hemoglobin düzeyi, hematokrit,eritrosit dağılım genişliği, ortalama trombosit hacmi ve trombosit dağılımı genişliği açısından benign durumları olan hastalar arasında istatistiksel olarak anlamlı bir fark yoktu. Ek olarak, gruplar arasında nötrofil/lenfosit oranı ve trombosit/lenfosit oranı açısından istatistiksel olarak anlamlı bir fark yoktu.

Sonuç: Hematolojik parametreler prostat biyopsi sonuçlarını öngörmede önemli bir rol oynamaz. Bu konunun daha fazla değerlendirilmesi için daha ileri çalışmalara ihtiyaç vardır.

Anahtar kelimeler: Biyopsi, nötrofil-lenfosit oranı, trombosit-lenfosit oranı, prostat
O. Karslı 0000-0002-6451-9149 University of Health Sciences, Derince Teaching and Research Hospital, Department of Urology, Kocaeli, Turkey

S. Yaylacı 0000-0002-6768-7973 Sakarya University, Faculty of Medicine, Department of Internal Medicine, Sakarya, Turkey

Cite as: Borekoglu A, Abat D, Eren $H$, Altunkol A, Karslı O, Yaylacı S. Do hematological param eters have a significant role in predicting the results of prostate biopsies?. Tepecik Eğit. ve Araşt. Hast. Dergisi. 2020;30(1):34-8. (c) Telif hakkı T.C. Sağıı Bakanlığı İmir Tepecik Eğit. ve Araşt. Hastanesi. Logos Tıp Yayıncılık tarafindan yayınlanmaktadır. Bu dergide yayınlanan bütün makaleler Creative Commons Attf-GayriTicari 4.0 Uluslararası Lisansı ile lisanslanmıştır.

(c) Copyright Association of Publication of the T.C. Ministry of Health İzmir Tepecik Education and Research Hospital. This journal published by Logos Medical Publishing. Licenced by Creative Commons Attribution-NonCommercial 4.0 International (CC BY-NC 4.0) 


\section{INTRODUCTION}

Approximately more than 1 million men are diagnosed with prostate cancer, and prostate cancer is the fifth leading cause of cancer-related deaths among men worldwide ${ }^{(1,2)}$. Prostate-specific antigen (PSA), also known as human kallikrein 3 , is secreted from prostate luminal cells and used as a diagnostic marker for the detection of prostate cancer ${ }^{(3,4)}$. PSA is a prostate-specific marker, but it is not specific for prostate cancer. Serum PSA levels may not only increase in patients with prostate cancer, but may also increase in patients with benign disorders such as benign prostatic hyperplasia and prostatitis. The positive predictive value of PSA is nearly $25 \%$ in patients with serum PSA levels over $4 \mathrm{ng} / \mathrm{ml}^{(5)}$. Furthermore, elevated PSA levels indicate the need for a prostate biopsy; however, $20 \%$ of patients with prostate cancer may be misdiagnosed in the first biopsy ${ }^{(6)}$. Some diagnostic tools are currently used for predicting the results of biopsies, such as the free/total PSA ratio, PSA density, PSA velocity, prostate cancer antigen 3, Prostate Health Index test and multi-parametric magnetic resonance imaging. However, none of these parameters provides exact accuracy for the prediction of prostate cancer. Recently, some studies have focused on the predictive and prognostic role of hematological parameters in prostate cancer. The neutrophil-to-lymphocyte ratio (NLR), mean platelet volume (MPV), platelet distribution width (PDW), and platelet-to-lymphocyte ratio (PLR) were assessed for that issue ${ }^{(2-7)}$. In the present study, we evaluated the role of NLR, PLR, $M P V$, red cell distribution width (RDW), PDW and plateletcrit (PCT) for predicting the results of the first prostate biopsy.

\section{MATERIAL and METHODS}

We assessed patients who underwent ultrasoundguided prostate biopsies between January 2014 and April 2016. The patients were divided into two groups according to their histopathological results as patients with and without established diagnosis of prostate cancer Hematological parameters, including the erythrocyte count, neutrophil count, lymphocyte count, platelet count, hemoglobin level, hematocrit level, red cell distribution width, mean platelet volume and platelet distribution width and plateletcrit, were measured before biopsy. The neutrophil-tolymphocyte and platelet-to-lymphocyte ratios were calculated according to the results. These parameters were compared between the two groups and statistically analyzed. The study was approved by the ethics committee of the Recep Tayyip Erdoğan University Faculty of Medicine,and all participants provided their written consent. The hematological parameters were analyzed with the Mindray BC-3200 auto hematology analyzer. Patients with diabetes, acute or chronic infection, kidney failure, liver disorders, hematological disorders or abnormal thyroid function tests were excluded from the study. Additionally, patients using anticoagulant therapy, steroids or alcohol and patients who had a previous history of cancer or hepatitis were excluded from the study.

\section{Statistical Analyses}

Statistical analysis was performed using SPSS 18.0 for Windows. Categorical variables were expressed as numbers or percentages, whereas continuous variables were expressed as mean \pm standard deviation. The Kolmogorov-Smirnov test was used to assess the normal distribution among continuous variables. If the distribution was normal, the data were compared using an independent variables t-test. A $p$ value of $<0.05$ was considered statistically significant.

\section{RESULTS}

We recruited 137 patients who underwent prostate biopsies to the study. Eleven patients who did not meet the inclusion criteria were excluded from the study. Finally, 126 patients were assessed. Prostate cancer was detected in 38 (30.25\%), and benign con- 
ditions (prostatic hyperplasia or chronic prostatitis) were diagnosed in 88 (69.85\%) patients. The mean ages in patients with prostate cancer and benign conditions were $69.47 \pm 8.7$ and $62.43 \pm 8.1$ years, respectively $(p=0.0001)$. There was no statistically significant difference between the patients with prostate cancer and benign conditions according to the white blood cell, neutrophil, lymphocyte, platelet counts, hemoglobin level, hematocrit, RDW, MPV, PDW and plateletcrit. Additionally, there were no statistically significant differences between the groups regarding NLR and PLR. The results are shown in Table 1.

Table 1. Hematological parameters of the patients with prostate cancer (PCa) and those with benign prostate hyperplasia (BPH).

\begin{tabular}{lccc}
\hline Parameter & PCa & BPH & p \\
\hline $\mathrm{n}(\%)$ & $38(30.15 \%)$ & $88(69.85 \%)$ & \\
Age (year) & $69.47 \pm 8.7$ & $62.43 \pm 8.1$ & 0.000 \\
WBC (K/uL) & $7475 \pm 1794$ & $7376 \pm 1890$ & 0.786 \\
RBC (M/uL) & $4.68 \pm 0.65$ & $4.81 \pm 0.44$ & 0.206 \\
Hemoglobin (g/dl) & $13.9 \pm 1.9$ & $14.2 \pm 1.5$ & 0.291 \\
HCT (\%) & $41.6 \pm 5$ & $42.5 \pm 3.9$ & 0.326 \\
Platelets (K/uL) & $223000 \pm 50000$ & $237000 \pm 65000$ & 0.241 \\
MPV (fl) & $9.28 \pm 1.3$ & $9.02 \pm 1.5$ & 0.367 \\
Neutrophil (K/uL) & $4528 \pm 1312$ & $4482 \pm 1554$ & 0.873 \\
Lymph (K/uL) & $2081 \pm 703$ & $2150 \pm 660$ & 0.599 \\
N/L ratio & $2.47 \pm 1.41$ & $2.26 \pm 1.13$ & 0.373 \\
P/L ratio & 120,9 & 116,8 & 0.636 \\
RDW (\%) & $14.08 \pm 2$ & $14.2 \pm 1.9$ & 0.745 \\
PDW (\%) & $15.8 \pm 2.1$ & $15.7 \pm 2.5$ & 0.820 \\
PCT (\%) & $0.2 \pm 0.05$ & $0.2 \pm 0.05$ & 0.597 \\
& & & \\
\hline
\end{tabular}

PCa: Prostate cancer, BPH: Benign prostatic hyperplasia WBC: White blood cell RBC: Red blood cell, HCT: Hematocrit MPV: Mean platelet volume, N/L ratio: Neutrophil-to-lymphocyte ratio, $P / L$ ratio: Platelet-tolymphocyte ratio, RDW: Red cell distribution width, PDW: Platelet distribution width, PCT: Plateletcrit

\section{DISCUSSION}

Prostate cancer is the most frequently detected cancer among men, and the pathological diagnosis is performed by a transrectal ultrasound-guided biopsy in most patients ${ }^{\left({ }^{8}\right)}$. Elevated PSA levels alert the physician of the need for a prostate biopsy. Some severe complications, such as urosepsis, urinary retention or excessive bleeding, can be seen after transrectal ultrasound-guided biopsies. Furthermore, nearly $25 \%$ of patients with elevated serum PSA levels are diagnosed with prostate cancer. Thus, most patients underwent an unnecessary biopsies and faced the potential complications of the biopsy. We need new markers with higher predictive values than PSA to prevent unnecessary biopsies. Currently, some authors have assessed the predictive and prognostic role of hematological parameters in prostate cancer using the neutrophil-to-lymphocyte ratio, mean platelet volume, platelet distribution width and platelet-to-lymphocyte ratio. These markers are easily applicable and cost-effective.

The neutrophil-to-lymphocyte ratio (NLR) is an inflammatory parameter, and inflammation has been reported to be related to tumor development ${ }^{(9)}$. Neutrophils are the predominant leukocyte in human blood, and their counts are increased during the systemic inflammatory response. Neutrophils release some cytokines, reactive oxygen species and proteases. These factors promote tumor cell proliferation and invasion. However, lymphocytes play an important role in the destruction of tumor cells and antitumor immunity ${ }^{(10)}$. Kawahara et al. ${ }^{(4)}$ assessed the predictive value of NLR as a biomarker in patients who underwent prostate biopsies and found that NLR was significantly higher in patients with detected prostate cancer than in patients without. Gokce et al. ${ }^{(6)}$ suggested that patients with prostate cancer and prostatitis had a higher mean NLR, so NLR is not a good marker for predicting prostate cancer prior to a prostate biopsy. In one study, patients were grouped according to the histology of the biopsy results, and the authors did not find any significant difference between the groups regarding NLR. The authors found a significant difference in NLR only in the subgroup of patients with PSA levels ranging from 4 to $10 \mathrm{ng} / \mathrm{ml}^{(11)}$. In a meta-analysis, the authors reported that an elevated NLR is not significantly associated with the prognosis of patients with localized prostate cancer; however, it is a good predictor of poor prognosis in patients with mCRPC ${ }^{(9)}$. In the present study, we found that NLR had no predictive value for discriminating prostate cancer from $\mathrm{BPH}$ prior to prostate biopsies. 
As mentioned above, there are many inconsistent results regarding the predictive value of NLR in the detection and prognosis of prostate cancer. Over the past two decades, we have come to understand that the cells of immune system in cancer perform two different actions as antitumoral and immunosuppressive activities, thereby leading to tumor progression ${ }^{(12)}$. Neutrophils and lymphocytes contain different subgroups. Neutrophils contain cells with an antitumor phenotype (N1) and a pro-tumor phenotype (N2), and some T lymphocytes have both pro- and antitumoral properties ${ }^{(10-12)}$. When we calculated the NLR, we considered all neutrophil and lymphocyte cells without discriminating between the subgroups. Therefore, the heterogeneity of the neutrophils and T lymphocytes can affect the NLR results. This heterogeneity may explain the inconsistent results obtained.

Studies have shown an increased platelet count in patients with different types of solid cancer, such as renal, breast, lung, colorectal and urogenital cancers. This mechanism is based on tumor-related humoral factors and cytokines such as interleukin-1, interleukin-6, thrombopoietin, granulocyte colonystimulating factor, granulocyte-macrophage colonystimulating factor, and basic fibroblast growth factor. These factors lead to megakaryopoiesis and thrombopoiesis. Additionally, some angiogenic factors, such as vascular endothelial growth factor produced by megakaryocytes, contribute in this way. Platelets contain active biomolecules in their granules. When platelets are activated by tumor cells, the active biomolecules are released. This process leads to tumor progression and invasion ${ }^{(13)}$. Additionally, platelets can aggregate around tumor cells. In this way, the tumor cells can be protected from lysis by naturel killer cells ${ }^{(2)}$.

We assessed the role of MPV, PDW, PCT and PLR in predicting prostate biopsy results. According to the present study, these parameters have no predictive value for discriminating prostate cancer from benign conditions. In one study the PLR results were compa- red among healthy individuals, patients with $\mathrm{BPH}$ and prostate cancer. The PLR was found to be significantly higher in patients with prostate cancer than in the other patients ${ }^{(14)}$. Yuksel et al. ${ }^{(5)}$ suggested that the NLR has no significant value in differing between $\mathrm{BPH}$ and prostate cancer. However, it was found that PLR had a value in differing between BPH and prostate cancer. Fu et al. ${ }^{(7)}$ reported that the combination of MPV, PDW and PSA level had higher sensitivity compared to PSA levels alone for detecting prostate cancer. There are limited number of studies on the predictive value of platelet-related parameters in the diagnosis of prostate cancer in the literature. Further studies are needed to confirm the role of the platelet-related parameters in prostate cancer. The reaction of the immune system to cancer is a very complex process. Thus, to identify the new predictive parameters or biomarkers for use in daily practice, we need to perform further studies on sophisticated predictive factors.

\section{CONCLUSIONS}

Hematological parameters such as RDW, PDW, MPV, PCT, NLR and PLR have no significant role for predicting the results of prostate biopsies. We believe that more sophisticated studies are needed to evaluate this issue.

Ethics Committee Approval: The approved number of the local ethics committee for this study was 25.11.2016/13 in the Recep Tayyip Erdoğan University of Medicine faculty (Rize,Turkey).

Conflict of Interest: The authors declare that there were no conflicts of interest.

Funding: None declared.

Informed Consent: All participants provided informed consent.

\section{REFERENCES}

1. Fanti S, Minozzi S, Antoch $\mathrm{G}$ et al. Consensus on molecular imaging and theranostics in prostate cancer. Lancet Oncol. 2018;19:e696-708. [CrossRef] 
2. Wang J, Zhou $X$, He $Y$ et al. Prognostic role of platelet to lymphocyte ratio in prostate cancer. Medicine. 2018;97(40):1-7. [CrossRef]

3. Fujita $\mathrm{K}$, Imamura R, Tanigawa $\mathrm{G}$ et al. Low serum neutrophil count predicts a positive prostate biopsy. Prostate Cancer and Prostatic Diseases. 2012;15:386-90. [CrossRef]

4. Kawahara T, Fukui S, Sakamaki K et al. Neutrophil-tolymphocyte ratio predicts prostatic carcinoma in men undergoing needle biopsy. Oncotarget. 2015;6(31):32169-76. [CrossRef]

5. Yuksel OH, Urkmez A, Akan $\mathrm{S}$ et al. Predictive value of the platelet-to-lymphocyte ratio in diagnosis of prostate cancer. Asian Pac J Cancer Prev. 2015;16(15):6407-12. [CrossRef]

6. Gokce MI, Hamidi N, Suer E, et al. Evaluation of neutrophilto-lymphocyte ratio prior to prostate biopsy to predict biopsy histology: Results of 1836 patients. Can Urol Assoc J. 2015;9(11-12):E761-5. [CrossRef]

7. Fu S, Zhang $X, N i u Y$ et al. Prostate spesific antigen, mean platelet volume, and platelet distribution width in combination to discriminate prostate cancer from benign prostate hyperplasia. Asian Pac J Cancer Prev. 2018;19(3):699-702.

8. Gu X, Gao X, Li X et al. Prognostic significance of neutrophilto-lymphocyte ratio in prostate cancer: evidence from 16266 patients. Sci. Rep. 2016;6:22089. [CrossRef]

9. Yin X, Xiao $Y$, Li F et al. Prognostic role of neutrophil-tolymphocyte ratio in prostate cancer. Medicine. 2016;95(3):1-8. [CrossRef]

10. Cao J, Zhu X, Zhao X et al. Neutrophil-to-lymphocyte ratio predicts PSA response and prognosis in prostate cancer: $A$ systematic review and meta-analysis. PLOS ONE. 2016:11(7):e0158770. [CrossRef]

11. Huang T, Mao S, Lu S et al. Predictive value of neutrophil-tolymphocyte ratio in diagnosis of prostate cancer among men who underwent template-guided prostate biopsy A STROBEcompliant study. Medicine. 2016:95(44):e5307. [CrossRef]

12. Dzinic SH, Bernardo M, Oliveira D et al et al. Tumor suppressor maspin as a modulator of host immune response to cancer. Bosn J Basic Med Sci. 2015;15(4):1-6. [CrossRef]

13. Plantureux L, Mege $D$, Crescence $L$ et al. Impacts of cancer on platelet production, activation and education and mechanisms of cancer-associated thrombosis. Cancers. 2018;10(441):1-23. [CrossRef]

14. Li F, Hu H, Gu S et al. Platelet to lymphocyte ratio plays an important role in prostate cancer's diagnosis and prognosis. Int J Clin Exp Med. 2015;8(7):11746-51. 